Věda a perspektivy № 7(7) 2021

ISSN 2695-1584 (Print)

ISST 2695-1592 (Online)

https://doi.org/10.52058/2695-1592-2021-7(7)-142-149

\title{
Владислав Мельник
}

кандидат юридичних наук,

викладач кафедри профілактики пожеж та безпеки життєдіяльності населення, Інститут державного управління та наукових досліджень 3 ичвільного захисту, м. Київ, Україна e-mail: melnykvladyslav@gmail.com https://orcid.org/0000-0002-2659-9942

\section{ПРАВОВЕ ЗАБЕЗПЕЧЕННЯ ПОЖЕЖНОЇ БЕЗПЕКИ В УКРАЇНІ}

Анотація. Актуальність дослідження зумовлена незадовільним станом пожежної безпеки в Україні, порушення вимог законодавства у цій сфері становить загрозу життю і здоров'ю людей та, як наслідок, може призвести до тяжких наслідків у сфері пожежної й техногенної безпеки.

Конституцією України людина, іiї життя і здоров'я, честь і гідність, недоторканність i безпека визнаються найвищою соціальною цінністю. Утвердження і забезпечення прав і свобод людини є головним обов'язком держави. 3 огляду на це одним 3 пріоритетних напрямів державної політики $\epsilon$ захист населення від пожеж і забезпечення належних заходів пожежної безпеки. Пожежна безпека має за мету забезпечення належного рівня захисту життя та здоров'я людей, майна та інших матеріальних цінностей і передбачає попередження, виявлення й ліквідацію пожеж та їх наслідків.

Акцентовано на необхідності посилення відповідальності за порушення пожежної безпеки задля більш відповідального дотримання громадянами i посадовими особами та фізичними особами - підприємцями вимог законодавства у сфері пожежної безпеки, що дозволить зменшити матеріальні втрати, спричинені пожежами, та мінімізувати кількість жертв від пожеж.

Ключові слова: пожежна безпека, ризик, пожежа, законодавство у сфері пожежної безпеки, адміністративна відповідальність, кримінальна відповідальність.

\section{Vladyslav Melnyk}

Candidate of legal sciences,

Lecturer of the Department of Fire Prevention and Life Safety, Institute of Public Administration and Research in Civil Protection,

Kyiv, Ukraine

e-mail:melnykvladyslav@gmail.com https://orcid.org/0000-0002-2659-9942

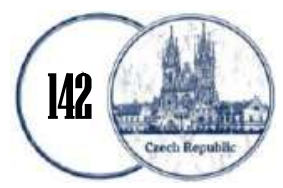




\section{LEGAL ASPECTS OF FIRE SAFETY IN UKRAINE}

Abstract. The topic's urgency is due to the unsatisfactory state of fire safety in Ukraine, violation of legislation in this area threatens human life and health and, as a consequence, can lead to serious consequences in the field of fire and technogenic security.

The Constitution of Ukraine recognizes man, his life and health, honour and dignity, inviolability and security as the highest social value. The establishment and protection of human rights and freedoms is the main duty of the state. In view of this, one of the priorities of state policy is to protect the population from fires and ensure appropriate fire safety measures. Fire safety aims to ensure an adequate level of protection of human life and health, property and other material values and provides for the prevention, detection and elimination of fires and their consequences.

Emphasis is placed on the need to strengthen liability for fire safety in order to more responsibly comply with the requirements of fire safety legislation by citizens and officials and individuals - entrepreneurs, which will reduce material losses caused by fires and minimize the number of victims of fires.

Keywords: fire safety, risk, fire, legislation in the field of fire safety, administrative liability, criminal liability.

Постановка проблеми. Стан пожежної безпеки в Україні сьогодні $є$ незадовільним, а порушення вимог законодавства у цій сфері становить загрозу життю і здоров'ю людей та може призвести до тяжких наслідків у сфері пожежної й техногенної безпеки. Статистика пожеж свідчить про значні матеріальні втрати і зростання кількості жертв від пожеж в Україні.

Підрозділами територіальних органів ДСНС України впродовж 10 місяців 2021 року в Україні зареєстровано 69923 пожежі, унаслідок яких загинула 1441 людина, у тому числі 23 дитини; 1146 людей отримали травми, у тому числі 78 дітей. Матеріальні втрати від пожеж становили 11 млрд 565 млн 553 тис. грн (із них прямі збитки - 2 млрд 730 млн 922 тис. грн, побічні - 8 млрд 834 млн 631 тис. грн) [1].

3 огляду на це посилення відповідальності за порушення вимог пожежної безпеки на території України, регулювання відносин у цій сфері органів державної влади, органів місцевого самоврядування та суб'єктів господарювання і громадян є нагальним та необхідним.

Аналіз останніх досліджень i публікацій. Питання забезпечення пожежної безпеки, превентивної діяльності у цій сфері, посилення відповідальності за порушення вимог пожежної безпеки $є$ предметом розгляду як представників органів державної влади, органів місцевого самоврядування, так і науковців і практиків. Також питання забезпечення пожежної безпеки перебуває на постійному контролі Президента України, про що свідчить низка 
підписаних Законів України, спрямованих на посилення відповідальності за порушення вимог пожежної та техногенної безпеки.

Метою статті $є$ дослідження стану правового забезпечення пожежної безпеки в Україні та відповідальності за порушення законодавства у цій сфері.

Виклад основного матеріалу. Щодня в Україні, в середньому, виникає 212 пожеж, матеріальні втрати від яких становлять 36 млн 481 тис. грн. Кожного дня внаслідок пожеж гине 4 людини, 3 людей отримує травми; вогнем знищується або пошкоджується 60 будівель (споруд) та 13 одиниць техніки. Прямі збитки від однієї пожежі становлять 41,5 тис. грн [1].

На об'єктах, на яких здійснюється державний нагляд (контроль) у сфері техногенної та пожежної безпеки, за 9 місяців поточного року виникло 1647 пожеж, що становить 2,8 \% від загальної кількості пожеж, унаслідок яких загинуло 28 людей та 61 людина отримала травми.

Прямі збитки від цих пожеж збільшилися у 3,2 рази і склали 1 млрд 138 млн 174 тис. грн, що становить 47,3 \% від загальної кількості прямих збитків; побічні збитки збільшилися у 2,9 рази і склали 2 млрд 89 млн 780 тис. грн, що становить 27,7 \% від загальної кількості побічних збитків. На одну пожежу на зазначених об’єктах припадає 691,1 тис. грн прямих збитків, у той час як середній показник на одну пожежу по всіх об’єктах складає 41,5 тис. грн, тобто менший у 16,7 рази [1].

Забезпечення пожежної безпеки на території України, регулювання відносин у цій сфері органів державної влади, органів місцевого самоврядування та суб'єктів господарювання і громадян здійснюються відповідно до Конституції України [2], Кодексу цивільного захисту України [3], законів та інших нормативно-правових актів.

Забезпечуючи пожежну безпеку, варто також керуватися Правилами пожежної безпеки в Україні, затвердженими наказом МВС України від 30 грудня 2014 р. № 1417 [4]; Національним стандартом України ДСТУ 8828:2019 «Пожежна безпека», затвердженим наказом Державного підприємства «Український науководослідний і навчальний центр проблем стандартизації, сертифікації та якості» (ДП «УкрНДНЦ») від 27 лютого 2019 р. № 38 [5]; іншими стандартами 3 пожежної безпеки, будівельними нормами, Правилами улаштування електроустановок (ПУЕ), нормами технологічного проєктування та іншими нормативними актами, що регламентують вимоги пожежної безпеки.

Відповідно до Кодексу цивільного захисту України пожежна безпека - це відсутність неприпустимого ризику виникнення i розвитку пожеж та пов'язаної з ними можливості завдання шкоди живим істотам, матеріальним цінностям і довкіллю [3].

Метою пожежної безпеки є забезпечення належного рівня захисту життя та здоров'я людей, майна та інших матеріальних цінностей, що передбачає попередження, виявлення й ліквідацію пожеж та їх наслідків.

Статтею 55 Кодексу цивільного захисту України передбачено, що 
забезпечення пожежної безпеки суб'єкта господарювання покладається на власників та керівників таких суб'єктів господарювання [3].

Державна служба України 3 надзвичайних ситуацій (далі - ДСНС України) організовує і здійснює державний нагляд (контроль) за додержанням вимог законів та інших нормативно-правових актів 3 питань техногенної та пожежної безпеки, цивільного захисту міністерствами, іншими центральними органами виконавчої влади, Радою міністрів Автономної Республіки Крим, місцевими держадміністраціями, іншими державними органами та органами місцевого самоврядування, суб'єктами господарювання [6].

За порушення встановлених чинним законодавством України вимог пожежної безпеки згідно з нормами Кодексу України про адміністративні правопорушення (далі - КУпАП) передбачено адміністративну діяльність [7]; Кримінальним кодексом України (далі - КК України) - кримінальну відповідальність [8].

Крім того, Президентом України підписано низку Законів України, спрямованих на посилення відповідальності за порушення вимог пожежної та техногенної безпеки. Зокрема, це Закон України «Про внесення змін до Кодексу України про адміністративні правопорушення щодо посилення відповідальності за порушення законодавства у сфері пожежної безпеки» від 03 лютого 2021 р. № 1187-IX, яким значно збільшено суми штрафів за порушення вимог пожежної безпеки [9]; Законом України «Про внесення змін до Кодексу України про адміністративні правопорушення щодо встановлення відповідальності за перешкоджання у проведенні перевірок з питань пожежної та техногенної безпеки» від 30 березня 2021 р. № 1367-IX встановлено адміністративну відповідальність за перешкоджання перевіркам ДСНС у вигляді штрафу від 1700 до 3400 грн, а за повторне порушення - штраф від 3400 до 5100 грн [10]; Законом України «Про внесення змін до Кодексу України про адміністративні правопорушення та Кримінального кодексу України щодо посилення відповідальності за порушення вимог пожежної та техногенної безпеки» від 30 березня 2021 р. № 1366-IX збільшено адміністративні штрафи за: завідомо неправдивий виклик спеціальних служб; невиконання приписів, розпоряджень чи постанов ДСНС [11].

Відповідно до КУПАП винні особи притягуються до адміністративної відповідальності за такі протиправні дії: порушення вимог пожежної безпеки в лісах - тягне за собою накладення штрафу: на громадян від дев'яноста до двохсот сімдесяти неоподатковуваних мінімумів доходів громадян (далі НМДГ $\left.{ }^{1}\right)$ і на посадових осіб — від двохсот сімдесяти до дев’ятисот НМДГ

1 Неоподатковуваний мінімум в КУпАП України зустрічається здебільшого для визначення розміру штрафів, а не для кваліфікації правопорушень. Для всіх абзаців, що починаються зі слів «тягне за собою накладення штрафу ...» використовуємо для розрахунку саме 17 гривень, а не податкову соціальну пільгу.

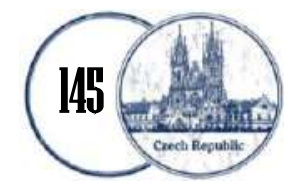


(ст. 77 КУпАП); самовільне випалювання рослинності або їі залишків тягнуть за собою накладення штрафу: на громадян від ста вісімдесяти до трьохсот шістдесяти НМДГ і на посадових осіб - від дев'ятисот до однієї тисячі двохсот шістдесяти НМДГ (ст. 77-1 КУПАП); порушення правил пожежної безпеки на залізничному, морському, річковому і повітряному транспорті (ст. 120 КУПАП); порушення встановлених законодавством вимог пожежної безпеки, а також використання пожежної техніки та засобів пожежогасіння не за призначенням - тягне за собою попередження або накладення штрафу: на громадян від 0,5 до семи НМДГ і на посадових осіб - від двох до десяти НМДГ (ст. 175 КУпАП); куріння тютюнових виробів у місцях, де це заборонено законом, - тягне за собою попередження або накладення штрафу від трьох до десяти неоподатковуваних мінімумів доходів громадян. Повторне протягом року вчинення порушення, за яке особу вже було піддано адміністративному стягненню, тягне за собою накладення штрафу від десяти до двадцяти неоподатковуваних мінімумів доходів громадян (ст. 175-1 КУПАП); початок роботи новоутворених підприємств або початок використання суб'єктом господарювання об’єктів нерухомості без зареєстрованої декларації відповідності матеріально-технічної бази вимогам законодавства у сфері пожежної безпеки (ст. 175-2 КУПАП); завідомо неправдивий виклик пожежної охорони (ст. 183 КУпАП); невиконання приписів та постанов посадових осіб центрального органу виконавчої влади, що реалізує державну політику з питань нагляду та контролю за додержанням законодавства про пожежну безпеку, або створення перешкод для їх діяльності передбачає відповідальність у вигляді попередження або накладення штрафу: на громадян від 0,5 до семи НМДГ і на посадових осіб - від двох до десяти НМДГ (ст. 188-8 КУПАП) [7].

Кримінальним кодексом України передбачена більш сувора відповідальність за порушення правил пожежної безпеки.

Так, у ст. 270 КК України зазначено, що порушення встановлених законодавством вимог пожежної безпеки, якщо воно спричинило виникнення пожежі, якою заподіяно шкоду здоров'ю людей або майнову шкоду у великому розмірі, - карається штрафом від однієї тисячі до чотирьох тисяч двадцяти неоподатковуваних мінімумів доходів громадян (від 17000 до 68340 грн) або виправними роботами на строк до двох років, або обмеженням волі на строк до трьох років, або позбавленням волі на той самий строк. Те саме діяння, якщо воно спричинило загибель людей, майнову шкоду в особливо великому розмірі або інші тяжкі наслідки, - карається позбавленням волі на строк від трьох до восьми років ${ }^{2}$.

2 Майнова шкода вважається заподіяною у великих розмірах, якщо прямі збитки становлять суму, яка в триста і більше разів перевищує неоподатковуваний мінімум доходів громадян, а в особливо великих розмірах - якщо прямі збитки становлять суму, яка в тисячу і більше разів перевищує неоподатковуваний мінімум доходів громадян.

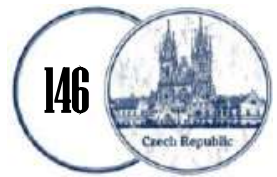


Стаття 367 КК України передбачено, що службова недбалість, тобто невиконання або неналежне виконання службовою особою своїх службових обов'язків через несумлінне ставлення до них, що завдало істотної шкоди охоронюваним законом правам, свободам та інтересам окремих громадян, державним чи громадським інтересам або інтересам окремих юридичних осіб, - карається штрафом від двохсот п'ятдесяти до п'ятисот неоподатковуваних мінімумів доходів громадян або виправними роботами на строк до двох років, або обмеженням волі на строк до трьох років, з позбавленням права обіймати певні посади чи займатися певною діяльністю на строк до трьох років. Те саме діяння, якщо воно спричинило тяжкі наслідки, - карається позбавленням волі на строк від двох до п'яти років 3 позбавленням права обіймати певні посади чи займатися певною діяльністю на строк до трьох років та зі штрафом від двохсот п'ятдесяти до семисот п'ятдесяти неоподатковуваних мінімумів доходів громадян або без такого [8].

Відповідальність за ст. 367 настає лише у випадку, якщо дії, невиконання чи неналежне виконання яких спричинило передбачені у зазначеній статті наслідки, входили у коло службових обов'язків цієї службової особи, іншими словами, якщо обов'язок діяти відповідним чином юридичне був включений (законом, указом, постановою, наказом, інструкцією тощо) до кола службових повноважень такої особи.

Для кваліфікації діяння за ст. 367 КК України потрібно встановити, що воно вчинене службовою особою під час виконання владних, організаційнорозпорядчих чи адміністративно-господарських функцій.

Аналіз законодавчого забезпечення пожежної безпеки дає підстави для висновку про те, що посилення відповідальності за порушення пожежної безпеки сприятиме більш відповідальному дотриманню громадянами i посадовими особами та фізичними особами - підприємцями вимог законодавства у сфері пожежної безпеки й дозволить зменшити матеріальні втрати, спричинені пожежами, i мінімізувати кількість жертв від пожеж.

Висновки. Підсумовуючи зазначимо, що лише заходами превенції пожеж неможливо покращити рівень пожежної безпеки. Сьогодні нашою державою вживається низка заходів, спрямованих на посилення встановлених законодавством вимог пожежної та техногенної безпеки, зокрема за невиконання приписів i постанов посадових осіб центрального органу виконавчої влади, що реалізує державну політику 3 питань нагляду та контролю за додержанням законодавства про пожежну безпеку, або створення перешкод для їх діяльності; за завідомо неправдивий виклик спеціальних служб; невиконання приписів, розпоряджень чи постанов ДСНС та ін. 
Věda a perspektivy № 7(7) 2021

ISST 2695-1584 (Print)

ISST 2695-1592 (Online)

\section{Лimepamypa:}

1. Аналітична довідка про пожежі та їх наслідки в Україні за 10 місяців 2021 року. Офіиійний вебсайт Інституту державного управління та наукових досліджень з изивільного захисту. URL: https://idundcz.dsns.gov.ua/files/2021/DOC/Analitychna\%20dovidka\%20pro\% 20pojeji_10.2021.pdf

2. Конституція України від 28 червня 1996 р. № 254к/96-BP. URL: https://zakon.rada.gov.ua/laws/show/254\%D0\%BA/96-\%D0\%B2\%D1\%80\#Text

3. Кодекс цивільного захисту України від 2 жовтня 2012 p. № 5403-VI. URL: https://zakon.rada.gov.ua/laws/show/5403-17\#Text

4. Правила пожежної безпеки в Україні: затверджено наказом МВС України № 1417 від 30 грудня 2014 р. Офіиійний вісник України. 2015. № 26. С.91. Ст. 767. URL: https://zakon.rada.gov.ua/laws/show/z0252-15\#Text

5. ДСТУ 8828:2019 ПОЖЕЖНА БЕЗПЕКА Загальні положення. Національний стандарт України: наказ Державного підприємства «Український науково-дослідний i навчальний центр проблем стандартизації, сертифікації та якості» від 27 лютого 2019 р. № 38. URL: https://zakon.isu.net.ua/sites/default/files/normdocs/dstu_8828_2019.pdf

6. Положення про Державну службу України з надзвичайних ситуацій: Постанова Кабінету Міністрів України від 16 грудня 2015 p. № 1052. URL: http://zakon2.rada.gov.ua/laws/show/1052-2015п

7. Кодекс України про адміністративні правопорушення від 7 грудня 1984 р. № 807410-ВР. Відомості Верховної Ради Української РСР (ВВР). 1984. Додаток до № 51. Ст. 1122, 1123, з наст. змінами. URL: http://zakon2.rada.gov.ua/laws/show/80731-10/stru/paran60\#n60.

8. Кримінальний кодекс України від 5 квітня 2001 р. № 2341-III. Відомості Верховної Ради України (ВВР). 2001. № 25-26. Ст. 131.

9. Про внесення змін до Кодексу України про адміністративні правопорушення щодо посилення відповідальності за порушення законодавства у сфері пожежної безпеки: Закон України від 3 лютого 2021 р. № 1187-IX. URL: https://zakon.rada.gov.ua/laws/show/1187-20\#Text

10. Про внесення змін до Кодексу України про адміністративні правопорушення щодо встановлення відповідальності за перешкоджання у проведенні перевірок 3 питань пожежної та техногенної безпеки: Закон України від 30 березня 2021 р. № 1367-IX. URL: https://zakon.rada.gov.ua/laws/show/1367-20\#Text

11. Про внесення змін до Кодексу України про адміністративні правопорушення та Кримінального кодексу України щодо посилення відповідальності за порушення вимог пожежної та техногенної безпеки: Закон України від 30 березня 2021 р. № 1366-IX. URL: https://zakon.rada.gov.ua/laws/show/1366-20\#Text

\section{References:}

1. Analitychna dovidka pro pozhezhi ta yikh naslidky v Ukraini za 10 misiatsiv 2021 roku [Analytical report on fires and their consequences in Ukraine for 10 months of 2021]. Ofitsiinyi vebsait Instytutu derzhavnoho upravlinnia ta naukovykh doslidzhen z tsyvilnoho zakhystu Official website of the Institute of Public Administration and Research in Civil Protection. URL: https://idundcz.dsns.gov.ua/files/2021/DOC/Analitychna\%20dovidka\%20pro\%20pojeji_10.2021.p df [in Ukrainian].

2. Konstytutsiia Ukrainy vid 28 chervnia 1996 r. № 254k/96-VR [Constitution of Ukraine of June 28, 1996 № 254k/96-VR]. URL: https://zakon.rada.gov.ua/laws/show/254\%D0\%BA/96$\% \mathrm{D} 0 \% \mathrm{~B} 2 \% \mathrm{D} 1 \% 80 \#$ Text [in Ukrainian].

3. Kodeks tsyvilnoho zakhystu Ukrainy vid 02 zhovtnia 2012 r. № 5403-VI [Code of Civil Protection of Ukraine of October 2, 2012 № 5403-VI]. URL: https://zakon.rada.gov.ua/laws/show/ 5403-17\#Text [in Ukrainian].

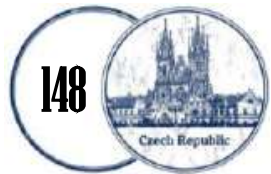




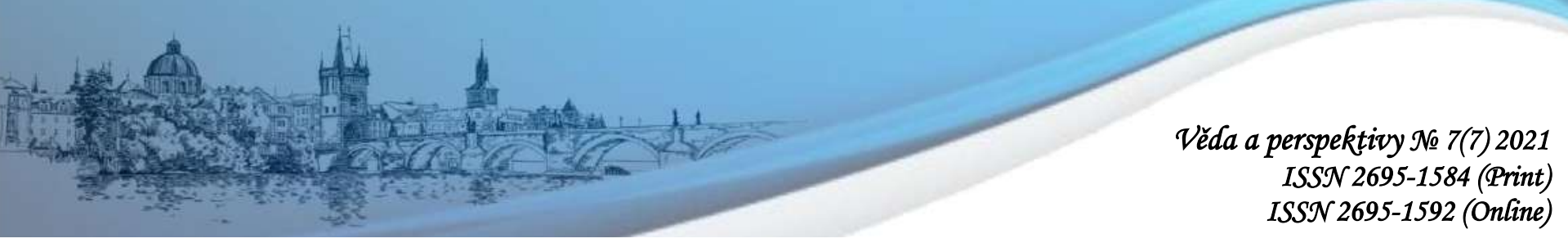

4. Pravyla pozhezhnoi bezpeky v Ukraini: zatverdzheno nakazom Ministerstva vnutrishnikh sprav Ukrainy № 1417 vid 30 hrudnia 2014 r. [Fire safety rules in Ukraine: approved by the order of the Ministry of Internal Affairs of Ukraine № 1417 of December 30, 2014]. (2015). Ofitsiinyi visnyk Ukrainy - Official Gazette of Ukraine, 26, p. 91. URL: https://zakon.rada.gov.ua/laws/ show/z0252-15\#Text [in Ukrainian].

5. DSTU 8828:2019 POZhEZhNA BEZPEKA. Zahalni polozhennia. Natsionalnyi standart Ukrainy: nakaz Derzhavnoho pidpryiemstva «Ukrainskyi naukovo-doslidnyi i navchalnyi tsentr problem standartyzatsii, sertyfikatsii ta yakosti» vid 27 liutoho 2019 r. № 38 [DSTU 8828: 2019 FIRE SAFETY. Terms. National Standard of Ukraine: Order of the State Enterprise "Ukrainian Research and Training Center for Standardization, Certification and Quality" of February 27, 2019 № 38]. URL: https://zakon.isu.net.ua/sites/default/files/normdocs/dstu_8828_2019.pdf [in Ukrainian].

6. Polozhennia pro Derzhavnu sluzhbu Ukrainy $\mathrm{z}$ nadzvychainykh sytuatsii: Postanova Kabinetu Ministriv Ukrainy vid 16 hrudnia 2015 r. № 1052 [Regulations on the State Service of Ukraine for Emergencies: Resolution of the Cabinet of Ministers of Ukraine of December 16, 2015 № 1052]. URL: http://zakon2.rada.gov.ua/laws/show/1052-2015ா [in Ukrainian].

7. Kodeks Ukrainy pro administratyvni pravoporushennia: vid 07 hrudnia 1984 r. № $8074-$ 10-VR [Code of Ukraine on Administrative Offenses: December 7, 1984 № 8074-10-VR] (1984). Vidomosti Verkhovnoi Rady Ukrainskoi RSR - Bulletin of Verkhovna Rada of the Ukrainian SSR. URL: http://zakon2.rada.gov.ua/laws/show/80731-10/stru/paran60\#n60 [in Ukrainian].

8. Kryminalnyi kodeks Ukrainy vid 05 kvitnia 2001 r. № 2341-III [Criminal Code of Ukraine of April 5, 2001 № 2341-III] (2001). Vidomosti Verkhovnoi Rady Ukrainy - Bulletin of Verkhovna Rada of Ukraine, 25-26 [in Ukrainian].

9. Pro vnesennia zmin do Kodeksu Ukrainy pro administratyvni pravoporushennia shchodo posylennia vidpovidalnosti za porushennia zakonodavstva u sferi pozhezhnoi bezpeky: Zakon Ukrainy vid 03 liutoho 2021 r. № 1187-IX [On Amendments to the Code of Ukraine on Administrative Offenses to Strengthen Liability for Violations of Fire Safety Legislation: Law of Ukraine of February 3, 2021 № 1187-IX]. URL: https://zakon.rada.gov.ua/laws/show/118720\#Text [in Ukrainian].

10. Pro vnesennia zmin do Kodeksu Ukrainy pro administratyvni pravoporushennia shchodo vstanovlennia vidpovidalnosti za pereshkodzhannia u provedenni perevirok z pytan pozhezhnoi ta tekhnohennoi bezpeky: Zakon Ukrainy vid 30 bereznia 2021 r. № 1367-IX [On Amendments to the Code of Ukraine on Administrative Offenses to Establish Responsibility for Obstacles to Conducting Inspections on Fire and Man-Made Safety: Law of Ukraine of March 30, 2021 № 1367-IX]. URL: https://zakon.rada.gov.ua/laws/show/1367-20\#Text [in Ukrainian].

11. Pro vnesennia zmin do Kodeksu Ukrainy pro administratyvni pravoporushennia ta Kryminalnoho kodeksu Ukrainy shchodo posylennia vidpovidalnosti za porushennia vymoh pozhezhnoi ta tekhnohennoi bezpeky: Zakon Ukrainy vid 30 bereznia 2021 r. № 1366-IX [On Amendments to the Code of Ukraine on Administrative Offenses and the Criminal Code of Ukraine on Strengthening Liability for Violation of Fire and Man-Made Safety Requirements: Law of Ukraine of March 30, 2021 № 1366-IX]. URL: https://zakon.rada.gov.ua/laws/show/136620\#Text [in Ukrainian]. 